\title{
Gabriel Marcel se lewe en werk as agtergrond van sy nadering tot God, Deel 2
}

\author{
Ernst Wolff \\ Tydelik-deeltydse dosent: Departement Godsdiens- en Sendingwetenskap \\ Universiteit van Pretoria
}

\begin{abstract}
Gabriel Marcel's life and work as background of his approach to God, Part 2

Having described Marcel's biography and the character of his thought, Part 2 of this essay continues by expounding the main themes of his philosophy. Firstly the nature and limits of human thought in relation to existence and being are explained. Secondly, closer attention is paid to participation. In the third section elements of Marcel's approach to God are sketched. The essay concludes with some critical comments.
\end{abstract}

\section{INLEIDING}

Dit behoort duidelik te wees uit my skets van die aard van Marcel se filosofie (Wolff 2000) dat 'n poging om die hoofmomente daarvan sorgvuldig uiteen te sit baie maklik 'n nie-Marceliaanse onderneming kan word. Die Marceliaanse manier waarop hierdie projek sy geloofwaardigheid kan behou, is om dit wat aangebied word, deur noukeurige denke te verbruik of te herwin.

In my aanbieding gaan ek eerstens kyk na die aard en beperkings van die mens se denkverhouding tot sy of haar eie eksistensie en tot die syn. Tweedens word die veld van partisipasie van die mens aan die syn ondersoek. Derdens bied ek 'n verkennende kykie

\footnotetext{
1 Hierdie artikel is ' $n$ verwerking van die tweede helfte van die BD-skripsie met dieselfde titel, wat gedurende September 1998 ingedien is en waarvoor prof L J S Steenkamp as studieleier opgetree het. Die skripsie is in groot dankbaarheid opgedra aan Izan Zybrands en Helena Dippenaar.
} 
aan oor die manier waarop Marcel sy denke in verband bring met God. Ten slotte word 'n waardering uitgewerk.

'n Natuurlike wegspringplek is die indiwidu se konkrete, alledaagse bestaan binne sy of haar spesifieke lewensituasie. Die mens besin oor hom/haarself en die wêreld as 'n manier om oor die weg te kom. Hierdie besinning kan op twee maniere gedoen word: 'n wetenskaplike of filosofiese manier, of eerder, soos Marcel dit noem: eerste en tweede refleksie.

\section{AARD EN BEPERKINGS VAN DIE MENS SE DENKE - EKSISTENSIE EN SYN}

\subsection{Eerste refleksie}

Die eerste refleksie is 'n poging om die lewensituasie te bemeester deur dit uit die konkrete kontingensie daarvan te abstraheer. So word die nadenke onafhanklik van die subjek wat besig is met die nadenke, tewens, alle mense geld as uitruilbaar. Daar word gesoek na algemeen geldende feite, wat mededeelbaar is. Die eerste refleksie hanteer die onbekende as probleme wat opgelos moet word en die ontwikkeling in hierdie omgaan met die wêreld vind plaas by grasie van die ontdekking van nuwe probleme, telkens wanneer oplossings vir probleme gevind word.

Bogenoemde abstraksie van iets uit die konkrete kontingensie daarvan, wat hierdie hantéring van die werklikheid moontlik maak, vind plaas deur die mens te verdeel in 'n denkende gees en 'n objek wat daarmee saamkom, genaamd die lyf. Die lyf word verstaan as die instrument waarmee die gees sintuiglike data vanuit die wêreld daarbuite versamel. $\mathrm{Na}$ analogie van die manier waarop die mens se lyf geobjektiveer word, word die wêreld ook geobjektiveer. Die denke verleen aan objekte in die wêreld 'n tipe geïsoleerdheid ten opsigte van die denke, met die gevolg dat objekte oěnskynlik van alle kante af benader kan word binne-in die ruimte waarin dit los lê (Marcel 1925:309). Met begrippe word name aan die objekte in die wêreld gegee. Wanneer hierdie begrippe tot 'n geslote sisteem saamgebind word, soos in teoriee of sisteme, kan dit die plek van die 
wêreld vir die mens inneem (soos ek reeds genoem het in verband met Marcel se kritiek teen sisteme). ${ }^{2}$

Marcel wil hierteenoor die primaat van eksistensie bo denke verdedig. Laat ek effens stilstaan by die manier waarop Marcel hierdie saak bedink.

\section{$2.2 \quad$ Tweede refleksie}

\subsubsection{Eksistensie versus objektiwiteit}

Die verhouding tussen mens en wêreld kan beter verstaan word teen die agtergrond van die manier waarop Marcel Josiah Royce se konsepsie van 'n triadiese verhouding tussen mens en wêreld in alle geestesaktiwiteite aanpas. ${ }^{3}$ Royce meen dat elke $e k$ 'n $j y$ teenoor hom/haar sien/veronderstel aan wie 'n derde, die dit gekommunikeer word. Die dit is die objek in die wêreld wat onafhanklik van ons gesien word (kyk Berning 1973:216-7). Die swakheid van hierdie beskouing kom na vore wanneer die dit 'n persoon is - om van 'n persoon in die derde persoon te praat (as 'n dit) is niks anders as om met jouself te praat en die ander persoon tot ' $n$ indeks van eienskappe te degradeer nie; persone kan net ervaar word in die werklikheid van Mitsein:

Indem ich aufhöre ihm bei mir selbst als dritte Person anzusehen, verăndert sich das triadische Verhältnis und wird mehr und mehr zu einer Zweiheit, zum dyadischen Bezug, denn das wesen, das ich liebe, ist so wenig wie moglich ein

2 Een belangrike toepassing van hierdie manier van omgaan met die werklikheid, is die wetenskap. As analise van die wêreld waaraan die mens deel het, is dit van groot waarde, soos byvoorbeeld deur die mediese wetenskap aangetoon word. Wanneer die eerste refleksie sosiaal toepassing vind, word dit gebruik om die funksie van mense in 'n samelewing te beskryf. Dit kan uitloop op pogings om die samelewing so te reêl, dat mense dan later bloot as sosiologiese funksies gedink word en so neem hierdie vorm van rasionaliteit ' $n$ ideologiese aard aan. Daarvan is die geskiedenis van die twintigste eeu vol voorbeelde. (Marcel se reaksie op die funksionalistiese hantering van die mens se lewe word later onder die hoof "Synsmisterie versus probleme" bespreek.)

${ }^{3}$ Die aanpassing van konsepsies, wat hulle ontstaan gekry het in die bedding van die eerste refleksie, na konsepsies, wat gepas is om uitdrukking te gee aan die deelname aan die synsmisterie, is vir Ricoeur die essensie van die tweede refleksie - "La réflexion seconde, appelée quelquefois reflexion recuperatrice, n'est pas autre chose que ce travail de rectification, au niveau des concepts et des mots, par quoi la penste tente de s'égaler à ce que $\mathrm{j}$ 'appelle dans mon 'Argument' les noyaux d'irréductibilite, constitutifs des experiences fondatrices” (Ricoeur [1984] 1992:50). 
Drittes für mich... Die Aufhebung des "Dritten" führt zum Sein, das sich dyadisch offenbart. Jedes Sein verhält sich prinzipiell personal zu jedem Sein.

(Berning 1973:217)

So word daar na analogie van die diadiese verhouding tussen mense, 'n diadiese verhouding tussen die syn van die mens en die syn buite die lyfhorison van die mens gesien. Hierdie insig sal geleidelik duideliker word. ${ }^{4}$

Wat Marcel probeer doen, is om binne die grootste moontlike konteks - dié van die verhouding tussen die mens en die werklikheid - die fundamentele primaat van eksistensie ${ }^{5}$ bo denke te nader deur eerstens die bestaan (existence) as onbetwyfelbaar te kies / af te kondig (Marcel 1925:312). Eksistensie ${ }^{6}$ (oftewel bestaan) is nie 'n attribuut of 'n predikaat wat aan dinge toegeskryf word nie. ' $L$ 'assurance [que l'existence est indubitable - EW] dont nous nous efforçons ici de dégager la nature ne saurait porter sur un caractère abstrait, pas plus d'ailleurs, que sur un cela auquel ce caractère appartiendrait, mais seulement sur l'indissoluble unité de l'existence et de l'existant." [Die versekering (dat eksistensie onbetwyfelbaar is), waarvan ek hard probeer om die aard duidelik te maak, kan nie berus op/betrekking hê op 'n abstrakte attribuut nie, nog minder trouens as op 'n ding, waaraan hierdie attribuut behoort, maar dit het net betrekking op die onverbreeklike eenheid van eksistensie en dit wat eksisteer (Marcel 1925:312-3).

\footnotetext{
${ }^{4}$ Kyk die wyses van deelname: my lyf en die verhouding $e k-j y$.
}

${ }^{5}$ Die essay waarin hierdie denke die eerste keer die lig gesien het, Existence et Objectivité (Marcel 1925) is die eerste plek waar die konsep existence, in die betekenisveld wat dit in die eksistensiefilosofie geniet, in Franse filosofie gebruik is. (Ek haal dus met vrymoedigheid rojaal daaruit aan.) Let daarop dat Marcel dit gebruik onafhanklik van Kierkegaard en voor die werk van Heidegger, Jaspers of Sartre.

"Dit lyk vir my of die konsepsie "eksistensie" hier dieselfde betekenis het as "syn". Daar moet egter gelet word op ' $n$ belangrike verskuiwing in Marcel se denke - In die essay onder bespreking (Marcel 1925) word "eksistensie" gebruik in die vraag oor die oorwinning van die subjek-objek skeiding (soos die opskrif, Eksistensie versus objektiwiteit, te kenne gee). Later (soos in Marcel [1933] 1949) word "syn" die sentrale begrip. Dan gaan dit oor die nadering van die synsmisterie en die vraag oor die ontologiese eis/begeerte. Dan word "eksistensie" gebruik vir die synswyse van die mens, in onderskeid van die syn. Die onderskeid kom na vore in Marcel se uitspraak: "Dieu n'existe pas, il est infiniment par delà l'existence". (aangehaal uit die Fragments philosophiques in Berning 1973:169), waandeur die onderskeid en die belang daarvan geillustreer word. 
Wanneer hierdie eenheid erken word, dan kan die eksistensie van die wêreld ook as onbetwyfelbaar, as gegee geneem word ("Ce qui m'est indubitablement donné, c'est l'expérience confuse et globale du monde en tant qu'existant ....") (Marcel 1925:313). Hierdie eksistensie is konstitutief vir die subjek aan wie die ervaring van die wêreld gegee is, ${ }^{7}$ want sonder 'n werklikheid waarvan die mens bewus kan word, is geen bewussynservaring moontlik nie. Met ander woorde, die bewussyn van eksistensie is die selfbewussyn van die subjek ("... à moins de parier délibérément contre l'existence, l'esprit se reconnaît muni d'une assurance indubitable portant non pas sur l'existence d'une chose particulière quelle qu'elle soit, non pas même sur l'existence en général, mais sur l'univers existant ...." [.... tensy die gees opsetlik teen bestaan wet, erken die gees dat dit voorsien is van ' $n$ onbetwyfelbare versekering betreffende, nie die bestaan van een of ander spesifieke ding nie, selfs nie bestaan in die algemeen nie, maar betreffende 'n bestaande heelal ....] [Marcel 1925:314]). As eksistensie dan nie 'n attribuut is wat aan iets toegeken word deur die rede nie en die bewussynservaring van die mens stem ooreen met die ervaring van die eksistensie van die werklikheid, dan is Marcel reg om die primaat van eksistensie (waarmee die paragraaf begin het) te aanvaar. ${ }^{8}$

As 'n mens oor die onbetwyfelbare primaat van die eksistensie bo die denke wil praat, dan kan dit net gedoen word by wyse van indirekte rede, soos Ricoeur ([1984] 1992:54) dit noem. Die indirekte rede is 'n poging om die deelname aan eksistensie oor te vertel. 'n Ander naam vir hierdie indirekte rede is die tweede refleksie.

\footnotetext{
${ }^{7}$ Uit die aard van die saak moet mens nie hier voor die versoeking swig om oor die subjek en die wêreld te dink in terme van 'n subjek-objek skeiding nie - die terme word net gebruik om die twee kante van die saak te onderskei.

8 Dit sal egter ' $n$ radikale kontradiksie wees om die voorafgaande as ' $n$ bewysvoering te verstaan. Die primaat van eksistensie kan tógrnie uit die rede afgelei word nie. "Que l'existence ne puisse être traitée comme un demonstrandum, cest ce qu'on ne peut au surplus manquer d'apercevoir, pour peu que l'on observe qu'elle est première ou qu'elle n'est pas, - mais ne peut en aucun cas être regardée comme réductible, comme dérivée.' (Marcel 1925:314). Die primaat van die eksistensie word op drie maniere in Marcel se denke uitgedruk: "... prise du côté de l'objet, on dira qu'elle marque l'indistinction entre l'existence et le ceci, sous peine de faire de l'existence un prédicat, la caractérisation d'un quelque chose saisi à part de son exister. Prise du côté du sujet [die teks lees verkeerdelik: de l'objet], on dira qu'elle est l'indivision du je et du suis, dans le $j$ 'existe incarné. Prise du côté de la relation sujet-objet elle-même, on dira que l'existence est le il y $a$ indivis, qui est aussi bien univers, corps, moi" (Ricoeur [1984]1992:54). Let op hoe hierdie drie deur my inleiding in Marcel se denke aan die orde kom.
} 


\subsubsection{Synsmisterie versus die problematiseerbare}

Uit die bespreking bo het dit geblyk dat die eerste refleksie met 'n analitiese dialektiek werk en die mens se deelname aan vrae buite rekening laat. Marcel se diagnose van die sosiale implikasies hiervan, is soos volg:

L'âge contemporain me paraît se caractériser par ce qu'on pourrait sans doute appeler la désorbitation de l'idée de fonction; je prends ici le mot de fonction dans son acception tout-à-fait générale, celle qui comprend à la fois les fonctions vitales et les fonctions sociales. L'individu tend à s'apparaitre à luimême et à apparaître aussi aux autres comme un simple faisceau de fonctions. [Dit lyk vir my of die tyd waarin ons leef, gekenmerk word deur wat ongetwyfeld 'n misplasing van die idee van funksies genoem kan word; ek gebruik die woord funksie hier in die wydste sin van die woord, wat sowel die vitale funksies as die sosiale funksies insluit. Die indiwidu neig om vir hom/haarself en ook vir ander te lyk soos 'n bondel/geheel van funksies.]

(Marcel [1933] 1949:46)

En terwyl die lewens- (vitale of fisiese) en sosiale funksies prominensie geniet weens die aandag wat teoriě soos psigo-analise en historiese materialisme daaraan gee, word die psigologiese funksies maklik in een van die ander twee funksies opgeslurp. Die mens se lewe toon die struktuur van 'n tabel van funksies en waar die "normale" funksionering onderbreek word deur siekte of dood, word die mens soos enige instrument op die fabrieksvloer gehanteer - herstel (gehospitaliseer) om weer te kan aanhou funksioneer of om bloot as verlies afgeskryf te word. In hierdie funksionalistiese wêreld word die misterie van gebeure, wat die vloei van sake onderbreek, byvoorbeeld geboorte, liefde en dood, wegverklaar deur die "catégorie psychologique et pseudo-scientifique du tout naturel" [psigologiese en pseudo-wetenskaplike kategorie van die "bloot/totaal natuurlike"] (Marcel [1933]1949:50), wat verklaring in terme van oorsaak en gevolg as volledig beskou. Vir persoonlike aangeleenthede en verwondering is daar al hoe minder ruimte. Maar dit is juis hierdie verwondering wat die besef by die mens wakker maak dat dit wat die mens is, aan hom of haar geskenk is. Uit die verwondering groei 'n honger, 'n 
begeerte na syn (vgl Berning 1974:283) ${ }^{9}$. Dit is wat Marcel die ontologiese behoefte/eis (exigence ontologique) noem. Mense ly aan 'n ontologiese gebrek in ' $n$ funksionalistiese samelewing; die manier waarop die mens se gedagtes altyd op ander, op die syn, gerig is ${ }^{10}$, word gestrem of verdoesel. Om hierdie probleem teë te werk, moet die mens weer van sy of haar eie synsmisterie bewus gemaak word, moet die mens se begeerte na syn (oftewel die ontologiese begeerte/eis) beter verstaan word.

Ons het reeds gesien dat Marcel die primaat van eksistensie bo denke verdedig. Met die vraag na wat dit is wat denke voorafgaan, grens Marcel hom af van die Duitse idealisme (waarin hy geskool is) in hulle poging om ' $n$ allesomvattende geheelsisteem van kennis te bou. Daarom is die vraag "Wat is ek?" so belangrik (kyk Marcel [1933] 1949:54-55; 1935:180-181; 1940:101-102). Wat is hierdie ek wat eksisteer, voordat ek hierdie of enige ander vraag kan vra en dan met die antwoorde begin filosofiese sisteme bou? Die antwoord betrek nie net vir my nie, maar ook die syn wat onderliggend aan alle denke is en waarop my denke gerig is. Omdat die vraag "Wat is ek?" nie van die raaisel van die syn geskei kan word nie, kan Marcel sê: “... nous sommes en présence d'un certain élan vers une affirmation qui, en dernière analyse, apparaît comme ne pouvant être établie; car je ne puis me juger qualifié pour l'énoncer qu'à partir de cette affirmation même." [... ons het hier te doen met 'n drang om 'n bepaalde bewering/bevestiging (aangaande die syn) te maak wat in die laaste analise lyk na iets wat nie beweer/bevestig kan word nie; want dit is eers nadat ek die bewering gemaak het dat ek myself kan beskou as in die posisie om die bewering te kan maak.] (Marcel [1933]1949:56). Hierdie "drang" is die ontologiese begeerte/eis, wat verstaan kan word as 'n sentrifugale krag in die wese van die mens, waarin die soeke na 'n toevlug tot uitdrukking kom (Ogiermann 1954:190). Die ontologiese begeerte/eis verraai 'n onvervuldheid, 'n onvergenoegdheid in die mens, wat as appèl ervaar word - ons word geroep om die beperkte vervulling van

\footnotetext{
9 In hierdie konteks praat Marcel ([1933]1949:52) van die syn as "... l'être est ce qui résiste - ou serait ce qui résisterait - à une analyze exhaustive portant sur les donnés de l'expériece et qui tenterait de les réduire de proche en proche à des élémentsde plus en plus dépourvus de valeur intrinsèque ou significative ...'

10 'La pensée n' est nullement relation avec soi-même, elle est au contraire par essence self-transcendance ... La pensée est tournée vers l'Autre, elle est appétence de l'Autre" (Marcel 1935:40).
} 
ons synsverlange te transendeer. Dit, sal ons sien, gebeur gedeeltelik in interpersoonlike verhoudings (trou, hoop, liefde), maar bo alles in die aanroep van God.

Die beperkings van die eerste refleksie kom nou duidelik na vore. Die vraag, "Wat is ek?" kan nie los van die ontologiese status van die ondersoeker gedink word nie. Hierdie vraag laat ook geen abstraksie toe nie; ek is nie met enige ander mens uitruilbaar in hierdie vraag nie. Ek is self die ondervraer en die ondervraagde, die vraag en die antwoord (Delfgaauw 1969:26). Die gevolgtrekking wat Marcel hieruit maak, is 'n fundamentele slotsom van sy denke:

Je m'oriente donc vers la position ou la reconnaissance d'une pariticipation qui possède une réalité de sujet; cette participation ne peut, par définition même, être objet de pensée; elle ne saurait faire fonction de solution, mais figure au delà du monde des problèmes: elle est méta-problématique ... Poser un méta-problématique, c'est penser le primat de l'être par rapport à la connaissance (non de l'être affirmé, mais plutôt de l'être s'affirmant) ... il y a bel et bien un mystère du connaître; la connaissance se suspend à un mode de participation dont une épistémologie quelle qu'elle soit ne peut espérer rendre compte parce qu'elle-même le suppose. [Ek wend my dus tot 'n stellinginname of 'n erkenning van 'n tipe partisipasie wat die werklikheid van 'n subjek het; hierdie paritisipasie kan per definisie nie die objek van denke wees nie; dit sou nie kon dien as 'n oplossing nie, dit verskyn eerder anderkant die domein van probleme: dit is meta-problematies .... Om aanspraak te maak op die meta-problematiese, beteken om die primaat van die syn bo kennis te bedink (nie die primaat van die syn wat gehandhaaf word nie, maar eerder van die syn wat sigself handhaaf)... daar bestaan 'n ware kenmisterie; kennis is afhanklik van 'n tipe partisipasie [aan die syn] waarvan geen epistemologie hoegemaand rekenskap sou kon geen nie, omdat so 'n epistemologie reeds die partisipasie veronderstel.]

(Marcel [1933] 1949:56-57)

Die syn is dit waaraan die mens deelneem, maar wat die mens oorskry, transendeer op verskillende maniere - as die wêreld, as die ander, as God (vgl Delfgaauw 1969:28 en sien my bespreking verder). Die vraag: "Wat is ek?" wat wortel in die 
ontologiese begeerte/eis, mond uit in die mens se openheid na die syn. Daar word op die vraag geantwoord, sal ons sien, binne interpersoonlike verhoudings waar trou, hoop en liefde weer naderings tot die synsmisterie is.

Deur erns te maak met die mens se deelname aan die syn, word die skeidings waarop die eerste refleksie berus - denke-ervaring" ${ }^{\prime \prime}$ denke-syn, subjek-objek - getransendeer. Die tweede refleksie kan nie geslote oplossings gee vir die onbekende nie, omdat die mens in die wêreld 'n oop, dinamiese ontvouing is. Dit nader die onbekende as metaprobleme, oftewel as misterie wat nie geobjektiveer kan word nie. Die refleksie oor misteries spruit voort uit die deelname aan misteries en mond uit in die mens se deelname aan misteries.

\section{DEELNAME (PARTICIPATION)}

Met behulp van die konsepsie van deelname kan Marcel se idees oor die verhouding tussen die mens en die werklikheid ondersoek word. Ek sal dit nou verder verduidelik met verwysing na ander terme, wat in die vorige paragraaf na vore gekom het.

\subsection{Misterie versus probleem}

Uit die voorafgaande moet dit nou blyk dat die eerste- en tweede refleksie twee fundamenteel verskillende benaderings tot die werklikheid verteenwoordig. Ons het gesien dat die twee denkwyses berus op twee verskillende visies op vraagstelling - eerste refleksie sien dit as objektiveerbare probleme wat opgelos moet word; tweede refleksie, as misteries waaraan 'n mens deelneem en wat genader moet word. Vandaar dan Marcel se definisie van die twee sentrale begrippe:

... un problème est quelque chose que je rencontre, que je trouve tout entier devant moi, mais que je puis par là-même cerner et réduire - au lieu qu'un mystère est quelque chose en quoi je suis moi-même engage ${ }^{12}$, et qui n'est par

\footnotetext{
"Soos geblyk het uit die bespreking van eksistensie versus objektiwiteit (1.2.1).

${ }^{12}$ Let op die gebruik van hierdie woord. Die konsepsie "engagement" sal later weer aan die orde kom.
} 
conséquent pensable que comme une sphère où la distinction de l'en moi et du devant moi perd sa signification et sa valeur initiale. [.... 'n probleem is iets wat ek teěkom, wat ek geheel en al voor my vind, maar wat ek juis daarom kan definieer en reduseer - daarteenoor is 'n misterie iets waarin ek self betrokke is, en wat gevolglik net gedink kan word as 'n sfeer waar die onderskeid tussen die in my en die voor my sy betekenis en aanvanklike waarde verloor.]

(Marcel 1935:169)

Soos met die verhouding tussen eerste en tweede refleksie, begin die misterie waar die probleem ophou, maar die misterie transendeer ook die probleem, terwyl die hantering van 'n probleem sekere sake veronderstel, wat vrae vir die tweede refleksie is. Die nie-skeibare verhouding tussen probleem en misterie word goed uitgedruk deur die sinoniem "metaprobleem" vir misterie te gebruik - so gesien is 'n misterie " ... un problème qui empiète sur ces propres données, qui les envahit et se dépasse par là même comme simple problème" [... 'n probleem wat inbreuk maak op sy eie data, wat dit as 't ware inneem en sigself so as blote probleem oorskrei.] (Marcel [1933] 1949:57).

Die begrip van misterie gee uitdrukking aan die primaat van die mens se (deelname aan) syn of eksistensie. Dit wil reg laat geskied aan die feit dat die syn sigself aan die mens opdring, nog voordat dit deur die mens bevestig kan word. Vandaar ook Marcel se eiesoortige manier van praat oor die wyse waarop ' $n$ mens met misterie moet omgaan, byvoorbeeld nader (approcher) ${ }^{13}$, erken of begroet ${ }^{14}$. En die eenheid wat bereik word, wanneer die skeiding van subjek en objek getransendeer word, word weergegee met woorde soos gegryp-wees, implikasie, engagement (Kampits 1975:66). Die tweede refleksie is dan die geskikte manier om met hierdie eenheid om te gaan. "Diese reflexion fuhrt für Marcel zu jenem Akt existentiellen Denkens, den er als 'recueillement', Sammlung, bezeichnet und der allein in der Lage ist, jene Seinsweisen zu erhellen, die

\footnotetext{
${ }^{13}$ Soos in die titel van sy 1933 essay - Position et Approches concrètes du Mystère ontologique.
}

\footnotetext{
14 "Si maintenant nous nous attachons à l'être entendu comme inépuisable concret, nous devrons observer d'abord qu'il ne peut pas à proprement parler faire fonction de donné, qu'il ne peut pas être constaté, mais seulement reconnu, - je serais même tenté de dire, si ce mot ne rendait un son insolite pour une oreille philosophique, moins reconnu que salué". (Marcel 1940:109-110). Sien ook endnota 22.
} 
nach Marcel einzig und allein einen zugang zum ontologischen Mysterium ermöglichen können: nämlich Treue, Hoffnung und Liebe" (Kampits 1975:66-7).

Dat daar 'n geskikte manier is om die misterie te nader, beteken egter nog nie dat 'n mens nie weer die misterie tot die status van 'n probleem kan degradeer nie. Dan word trou trae konformisme, hoop word optimisme en liefde word voorkeur. Een plek waar die verskil tussen probleem en misterie duidelik na vore kom, is die verhouding van syn en hê.

\subsection{Syn en hê}

In hê en syn meen Marcel dat hy eksistensiële grondkategorieë gevind het, wat dus betrekking het op die mens in die konkrete situasie' en nie op die mens as denker nie.

Hê is 'n verhouding wat altyd in die rigting van 'n Qui (ek, self) na 'n Quid (ding, onderwerp) werk. Hê beteken altyd iets hê. Hierdie iets is onafhanklik van die mens; dit is iets, wat die persoon wat het, nie is nie. 'n Mens kan (in beginsel) daaroor beskik. Die houding van die $Q u i$ teenoor die Quid, kan beskryf word as 'n toeskouersposisie. Dit is ook die posisie van waaruit eienskappe aan iets toegeskryf word. Tipies van hierdie posisie is begeerte of hebsug. Die eerste indruk, naamlik dat dit hier gaan oor ' $n$ intense bemoeienis met die werklikheid buite die mens is bedrieglik - eintlik gaan dit om 'n selfbemoeienis, die mens wat in hom/haarself keer en hom/haarself ten opsigte van die werklikheid/syn afsluit.

Uit hierdie skets van hê moet die kontras met syn al blyk: "Nous exposons ce que nous avons, nous révélons ce que nous sommes (partiellement, bien entendu). "[Dit wat ons het, sit ons uiteen/stel ons bloot, ons openbaar dit wat ons is (gedeeltelik, natuurlik).] (Marcel 1935:196). Hê en syn is nie los van mekaar te dink nie. Daar is 'n wedersydse afhanklikheid; die moontlikheid van hê berus op die gegewenheid van syn (Marcel 1935:194-5). Hierdie verhouding verander van waarde in sekere betekenismoontlikhede. Marcel illustreer dit met die uitdrukking "avoir conscience" (letterlik: bewussyn te hê) wat dieselfde beteken as om bewus te wees (gesien teen die agtergrond van die onskeibaarheid tussen selfbewussyn en syn, wat reeds bespreek is). Hê het dus 'n spanning tussen twee pole van betekenis. Die eerste is besittende hê en die tweede impliserende hê. Dit is laasgenoemde tipe hê wat die betekenis van syn nader. 
Besittende hê is 'n probleem; impliserende hê nader 'n misterie, namate dit meer met die betekenis van syn ooreenstem. Een voorbeeld hiervan is my lyf.

\subsubsection{My lyf}

Tipies van die modernisme se houding teenoor die lyf is Descartes se opinie: Die denkende subjek besit ' $n$ lyf waaroor hy of sy beskik as objek of as instrument. Hierdie houding teenoor die lyf is tekenend van die subjek-objek dualisme en objektiwiteitsdenke, waarteen Marcel hom verset. Hy beveg die Cartesiaanse visie van die kant van die objek, deur die primaat van ervaring bo denke te herstel ${ }^{15}$ en van die kant van die subjek beveg hy dit deur die inkarnasie van die mens (Ricoeur [1984]1992:53).

Die objektiwistiese beeld van die lyf is dat dit ' $n$ instrument is waarmee die subjek sintuiglike data insamel. Wanneer ' $n$ liggaam ' $n$ instrument gebruik, dan dien daardie instrument as ' $n$ verlenging en spesialisasie van die werking van die liggaam. Maar as ons nou een tree terug gee, wat is dit wat die liggaam as instrument gebruik? Dit is ò 'n fisiese gees of dit is 'n tipe liggaam, wat self weer die instrument van 'n ander liggaam is, wat die instrument van ' $n$ ander liggaam is ... Laasgenoemde oneindige regressie los nie die probleem op nie. Eersgenoemde kom neer op 'n materialisme - die gees (subjek, ek) word van die liggaam afgelei, of anders gesê, my lyf is 'n objek, ek is niks nie. Maar wat is dan hierdie objek, waarvan is dit die objek? Dit is die objek van 'n selfbewuste ek waarvan die bestaan juis ontken word. Die materialisme deug dus ook nie (vgl Marcel 1925:323; Berning 1973:210-211).

Volgens Marcel is selfbewussyn altyd reeds bewussyn van ' $n$ lyf. Die lyf is ' $n$ tipiese voorbeeld van die betekenisspanning van hê. Die besitlike voornaamwoord "my" dui nie op 'n besittende hê nie, maar op 'n impliserende hê, oftewel 'n syn: “... de ce corps je ne puis pas dire ni qu'il est à moi, ni qu'il n'est pas moi, ni qu'il est pour moi (objet); Je ne me sers pas de mon corps, je suis mon corps." [.... van my lyf kan ek nòg sê dat dit aan my behoort, nòg dat dit nie ek is nie, nòg dat dit vir my ('n objek) is; Ek bedien my nie van my lyf nie, ek is my lyf.] (Marcel 1935:12 en 1925:323). Dit is dus ongeldig om van ek en my lyf te praat. Dit blyk dat die geïnkarneerdheid van die mens

\footnotetext{
is Hierna het ons reeds gekyk onder die opskrif van eksistensie versus objektiwiteit (1.2.1).
} 
vir Marcel ' $n$ misterie is. Dit beteken egter nie dat die mens nie die lyf soos ' $\mathrm{n}$ ding kan behandel nie. Selfmoord is ' $n$ tragiese voorbeeld van waar ' $n$ mens nie meer sy of haar lyf wil hê nie.

Die manier hoe die mens dan aan die syn deelneem is inkarnasie. Die geïnkarneerdheid van die mens gaan sy of haar denke vooraf en daar is geen direkte verbinding tussen deelname en refleksie nie ${ }^{16}$. Die denke kan op geen manier die lyfhorison van die mens oorskry nie, maar dit sal verkeerd wees om te dink dat die lyf daarom die grens van die refleksie sou wees. So 'n gevolgtrekking sou verklap dat iemand weer die lyf as ' $n$ objek begin sien (sien Berning 1973:316).

Vanuit hierdie perspektief kan eksistensie nou gesien word as ".... dasjenige, was sich mir in meiner geistig-körperlichen Erfahrung vergegenwärtigt. Existenz bleibt an die Sphäre der konkreten Leiblichkeit gebunden, und ist daher stets kontingent" (Berning 1973:168). Hierdie deelname, wat my inkarnasie is, is die model na analogie waarvan my deelname aan die eksistensie van die res van die werklikheid gesien word. Die res van die werklikheid word ook gesien as 'n verlenging van my lyf. So word die $e k$ die middelpunt van die wêreld, in die sin dat die $e k$ in die wêreld geïnkarneer is - dit is nog 'n manier om die oorskryding van die subjek-objek skeiding te beskryf. My geïnkarneerdheid is ook die manier waarop ek ruimtelike in die wêreld aanwesig is. Maar ek staan nie teenoor die wêreld in 'n hê-verhouding nie (ontologies gesproke) of soos 'n toeskouer nie; ek is aan die wêreld verbind, soos ek aan my lyf verbind is ${ }^{17}$.

\footnotetext{
16 "La participation apparaît donc maintenant comme la limite supérieur de la réflexion, c'est à dire comme l'acte devant lequel toute réflexion doit s'arrêter. Il n'y a pas, nous le savons, de passage de la participation à la réflexion" (Marcel, aangehaal uit die Fragments Philosophiques, p.60 in Berning 1973:170).

${ }^{17}$ Die woord wat Marcel hier gebruik, is engagement. Die begrip is nie net belangrik vir Marcel se denke omdat dit 'n kembegrip vir die verhouding tussen mens en wêreld is nie; dit is 'n begrip wat hy aan die eksistensialisme bekendgestel het. Die term is moeilik om te vertaal en word in Nederlands, Duits en Engels net so oorgeneem. Aan die een kant beteken dit 'n deelname aan en geïnteresseerd wees in die werklikheid. Aan die ander kant verwys dit na die mens se vermoe om betrekkings aan te knoop of op te sê: "Err [der Mensch] flieht das Engagement, weil es ihn beansprucht, weil es schwer ist, seine Verpflichtung auf sich zu nehmen und der Mensch lieber ungebunden dahinleben morchte. Aber indem er sich dem Engagement entzieht, verliert er die eigentliche Substanz des Lebens, sein Leben erleert sich, un er findet umgekehrt die volle Erfullung erst wieder im Engagement". (Bollnow 1965:90).
} 


\title{
3.3 Beskikbaarheid (disponibilité)
}

Deelname aan die syn is nie objektiveerbaar of objektiverend nie, daarom is dit 'n misterie. Dit beteken dat die mens mede-gevorm word deur dit waaraan ' $n$ mens deelneem. Een manier waarop Marcel hierdie saak belig is met die verskynsel van liefde ${ }^{18}$ :

\begin{abstract}
Si je mets l'accent sur le fait que c'est quelqu'un qui aime quelqu'un d'autre (fut-ce moi-même), il devient impossible pour moi de ne pas traiter cet amour comme un phénomène, une affection. Si au contraire je participe à l'amour, je ne tenterai plus de le faire entrer dans mes cases logiques: tout au contraire c'est moi-même tout entier que je refondrai pour pénétrer en lui; je ne le subordonne pas à moi, je me subordonne à lui. [As ek die aksent plaas op die feit dat dit iemand is wat iemand anders liefhet (al is dit ook myself), dan word dit onmoontlik vir my om hierdie liefde anders te hanteer as 'n verskynsel, 'n gevoel. As ek daarenteen deelneem aan die liefde, sal ek nie meer probeer om dit in my logiese kompartemente te maak pas nie: presies die teenoorgestelde - dit is ek, wat myself ten volle re-organiseer om dit te deurgrond; ek stel dit nie ondergeskik aan my nie, ek onderwerp myself daaraan.]
\end{abstract}

(Marcel 1927:227)

Ek het vroeèr genoem dat die ontologiese begeerte die mens oopmaak na die syn en dit is hier waar die oorgang na beskikbaarheid gemaak word: Die oorgang van "om iets aan jouself te onderwerp" na "om jouself aan iets te onderwerp" soos Marcel dit met verwysing na die liefde beskryf, “... bedeutet einen Übergang von der 'indisponibilité zur 'disponiblité', von der 'Undurchlässigkeit' zur 'Durchlassichkeit', von der Selbstverschlossenheit $^{19}$ zur Geöffnetheit dem Anderen, oder, wie hier ohne weiteres gesagt werden kann, dem Sein gegenuber" (Kampits 1975:70-1). Beskikbaarheid hoort dus tot die syn en die misterie, terwyl nie-beskikbaarheid hoort tot hê en die problematiese. Wat ' $n$ beskikbare persoon is, kan verder verduidelik word aan die hand van interpersoonlike

18 Ek het vroetr reeds genoem dat liefde een van die maniere van toegang tot die synsmisterie is.

19 Waarna ons gekyk het by die besittende hê. 
verhoudings: wanneer ek nodig het om op iemand te vertrou, kry ek by sommiges die gevoel dat hulle nie beskikbaar is nie (selfs al help hulle) en by ander ervaar ek ' $n$ sekere teenwoordigheid (présence) (selfs al kan hulle nie help nie). Die verskil tussen die twee is dit: “... l'être disponible est celui qui est capable d'être tout entier avec moi lorsque j' ai besoin de lui; l'être indisponible est au contraire celui qui semble opérer en ma faveur une sorte de prélèvement momentané sur l'ensemble des ressources dont il est en mesure de disposer. Pour le premier je suis une présence, pour le second je suis un objet. [... die persoon wat beskikbaar is, is die een wat in staat is om ten volle saam met my te wees wanneer ek hom nodig het; die persoon wat nie beskikbaar is nie, is aan die ander kant die een wat lyk of hy in my guns 'n soort tydelike lening bied uit die geheel van dit waaroor hy beskik. Vir die eerste een is ek teenwoordig, vir die ander is ek 'n objek.] (Marcel [1933] 1949:83). En so het ons reeds by die verhouding tussen mense gekom.

\subsubsection{Die verhouding tussen mense (Mitsein)}

Die plek waar die gebrekkigheid van die eerste refleksie/die problematiese/die objektiwisme by uitnemendheid na vore tree, is die verhouding tussen mense. Die subjek is nie vir die objek wat die objek vir die subjek is nie - hoeveel te meer is die verhouding tussen twee subjekte dan anders. Ons het reeds hierbo (1.2.1) gesien hoe Marcel Royce se verstaan van 'n epistemologiese triade omvorm na 'n diade in die tweede refleksie wanneer ek ' $n$ ander ontmoet dan staan hy/sy nie as 'n dit teenoor my nie, maar as ' $n j y$. So word dieselfde gevolgtrekking gemaak vanuit die openheid of beskikbaarheid van die mens teenoor die syn, wat in die vorige paragraaf aan die orde gekom het:

Dies Geoffnetsein, dieses Offenstehen fuhrt für Marcel direkt zur Erfahrung des Anderen als $\mathrm{Du}$, ja es erscheint nachgerade als die Bedingung für die Möglichkeit, den Anderen als Du zu erfahren. Denn bereits Marcels Kritik an der Subjektivităt zeigte, daß der Andere nur dann als Anderer, und das heißt als Du, erfahren werden kann, wenn ich ihm geoffnet bin.

(Kampits 1975:72) 
Hier betree ons dan Marcel se filosofie van dialoog oftewel sy personalisme ${ }^{20}$. Die verhouding tussen $e k$ en $j y$ vertoon die volgende ooreenkomste met die filosofie van Buber (kyk Levinas [1978]1987:35-38):

- Die verhouding $e k$-jy word verstaan in kontras met die verhouding $e k$-dit; sosialiteit geniet primaat bo die subjek-objek struktuur.

- 'Les deux philosophes s'accordent dans leur mise en question du primat spirituel de l'objectivisme intellectualiste, qui s'affirme dans la science prise pour modèle de toute intelligibilité, mais aussi dans la philosophie occidentale dont cette science est issue ... Ce n'est pas la vérité qui serait la signification ultime de cette relation, mais la socialité irréductible au savoir et à la vérité." [Albei filosowe bevraagteken die geestelike primaat van die intellektualistiese objektiwisme, wat sigself beaam in die wetenskap (wat beskou word as model vir alle verstaanbaarheid), maar ook in die Westerse filosofie, waarvan hierdie wetenskap 'n gevolg is .... Dit is nie die waarheid wat die uiteindelike betekenis van hierdie verhouding sou wees nie, maar die sosialiteit, wat nie tot kennis of tot die waarheid gereduseer kan word nie.] (Levinas [1978]1987:37-8).

- Die $j y$ by uitnemendheid is die Absolute of Ewige $J y$ - God - wat die basis vir interpersoonlike verhoudings is. Menslike spiritualiteit of godsdiens wortel in die ervaring van 'n mens as 'n mens voor ander mense.

- Die rede vir die verhouding is nie in die $e k$ of in die jy geleë nie, maar in 'n dimensie wat met die voorsetsel "tussen" (zwischen; entre-les-deux) weergegee word.

- Die verhouding $e k-j y$ word in terme van die syn uitgedruk; "tussen" is 'n ontologiese kategorie. Dit word verstaan as samesyn, Mitsein, co-esse.

\footnotetext{
${ }^{20}$ Die nadenke oor die verhouding $e k-j y$, word meesal met Martin Buber in verband gebring. Sy bekende boek Ich und $D u$ het in 1923 verskyn. Terselfdertyd en onafhanklik van Buber het Marcel oor dieselfde onderwerp nagedink en tot baie dieselfde gevolgtrekkings gekom. Sy ontwikkeling op hierdie terrein kan gevolg word in die tweede deel van sy Journal Métaphysique (1915-1923), maar die werk is egter eers in 1927 uitgegee.
} 
Ons kan egter ook iets oor Marcel se personalisme te wete kom deur dit met dié van Buber te kontrasteer. Die fundamentele beginsel vir Buber is: "in die begin was die verhouding" en die konkrete verwerkliking by uitnemendheid hiervan is dialoog (Levinas [1978]1987:39). Vir Marcel is daar 'n meer direkte wyse waarop die verhouding konkreet beliggaam word. Deur my lyf het ek deel aan 'n gemeenskap van geïnkarneerde mense en ek neem hierdie geïnkarneerde wesens nie op as objekte nie, maar telkens as 'n ander geïnkarneerde $e k$, met wie ek in verhouding is. Onderliggend aan hierdie diadiese verhouding is almal se deelname aan die ontologiese misterie (vgl Berning 1973:319 en kyk die opmerking van Kampits oor openheid tot die syn hierbo). Teenoor die term "verhouding" (wat Buber gebruik) verkies Marcel "ontmoeting" of "spanning". Ons ontmoet ook nie almal met wie ons paaie kruis nie. Die ontmoeting is daardie oorgang van om langs iemand te wees, na om by of saam met iemand te wees ${ }^{21}$. Hierdie samesyn (Mitsein, être-avec) kan nie verobjektiveer word sonder om die "saam met"-aard daarvan in die slag te laat bly nie. Daarom kan dit nie bewys word nie en geen (objektiewe) kriteria kan daarvoor gegee word nie. Die teenwoordigheid ${ }^{22}$ van die ander mens is, soos in ander gevalle van deelname, nie iets wat tot beskikking van 'n denkende subjek staan nie - "sie kann nur angerufen werden (appellée), nur auf- und hervorgerufen werden (evoquée ou invoquée), ja im Grunde wieder nur willkommen geheißen, begrußt werden (être accueillie)" (Kampits 1975:78). Maar hierdie aanroep van 'n ander mens moet 'n ontologiese fundering hê. Die gemeenskaplike grond vir die samesyn is die liefde, wat die aanroeping voorafgaan - liefde is die teenwoordige deelname aan die syn, wat die persoon wat liefgehê word, konstitueer (sien bespreking van liefde verder). Die liefde is skeppend, nie in die sin dat die subjek self ' $n$ voorwerp van liefde in die lewe roep nie, maar omdat die ander eers ' $\mathrm{n} j \mathrm{y}$ word wanneer hy/sy liefgehê word.

\footnotetext{
21 'n Relevante illustrasie hiervan vind ons in Marcel se eie lewe: die mense met wie hy te doen gekry het as beampte van die Rooi Kruis kon vir hom name op amptelike stukke bly of hy kon hulle as mede-mense in hulle situasie, as $j y$, ontmoet. Die vele probleme in verband met interpersoonlike verhoudings word ook gepas in sy drama hanteer.
}

22 Ek het hierdie belangrike term reeds aangeroer (kyk 2.3: "Vir die een is ek teenwoordig; vir die ander is ek 'n objek" [Marcel [1933]1949:83]). En wat ek vroekr oor die nadering tot misteries gesê het (kyk voetnota 13), is by uitnemendheid waar vir teenwoordigheid/présence - "La présence est quelque chose qui se révèle immédiatement et irrécusablement dans un regard, un sourire, un accent, un serrement de mains" (Marcel [1933]1949:83). 
Wanneer ek in liefde die grens tussen dit voor my en dit in my oorskry (kyk Marcel 1935:169 bo aangehaal), wanneer ek in liefde die dit kans gee om jy vir my te word, dan is $e k$ en $j y$ nie meer net twee alleenstaande persone nie. Ek en jy word ons. En in die ons is ek en jy gelyk oorspronklik - daar is geen hiërargie in die intersubjektiwiteit nie. Die liefde is ' $n$ wedersydse bevryding van $e k$ en $j y$ om onsself te word deur ons openheid vir mekaar. Net so is 'n geslotenheid teenoor ander selfvervreemding. In aansluiting by die skeppende aard van liefde waarna ek verwys het, kan ' $n$ mens dan saam met Marcel sê: "Au fond, jẹ ne puis dire valablement je m'appartiens que dans la mesure où je crée, où je me crée, c'est-à-dire, reconnaissons-le, où, métaphysiquement parlant, je ne m'appartiens pas." [Eintlik kan ek net met reg beweer dat ek aan myself behoort vir sover ek skep of sover ek myself skep, dit wil sê, ons moet dit toegee, vir sover, metafisies gestel, ek nie aan myself behoort nie.] (Marcel 1940:149). My openheid tot ander mense verander my dus ook en dit laat my tot myself word. Die probleem van die spanning tussen heteronomie en outonomie word in die metaprobleem oftewel die misterie van deelname, van ons, getransendeer. En die metaproblematiese is 'n deelname wat my werklikheid as subjek begrond (ons behoort nie aan onsself nie) - "le métaproblématique, c'est une participation qui fonde ma réalité de sujet (NOUS NE SOMMES PAS A NOUS-MÊMES) ...." (Marcel 1935:165) ${ }^{23}$. Die mens is heterosentries.

\section{MARCEL EN DIE NADERING TOT GOD}

Met hierdie oorsig oor belangrike temas uit Marcel se denke, kan ons nou kyk na wat hy oor God te sê het.

\footnotetext{
${ }^{23}$ Sonder dat ek daarop kan ingaan, wys ek op 'n belangrike dilemma: 'n Marcel se dialogisme. Hoe vind Marcel 'n balans tussen die eenheid van ons en die onderskeid tussen ek en $j y$, wat onder andere met die lyf gegee word? Kan die andersheid van die ander tot sy reg kom, sonder dat ek en jy weer teenoor mekaar te staan kom en hoe kan ons hierdie teenoorstaan transendeer in samesyn sonder om tot mekaar gereduseer te word? Dat Mancel hom voortdurend weer met hierdie saak bemoei het, dui al op die kompleksiteit daarvan. Vir 'n volledige bespreking, kyk Kampits (1975:125-136).
} 


\subsection{Oor die Godsbewyse}

In Marcel se bemoeienis met die Godsbewyse wil hy nie soseer die bestaan van God bewys nie as dat hy die manier hoe die mens tot God (moet/kan) nader, wil ophelder. Ons moet hier twee dinge in gedagte hou. Eerstens, Marcel ontken nie dat die mens seker kan wees oor die bestaan van God nie, maar die "bewyse" is volgens hom nie die manier hoe die mens by hierdie sekerheid uitkom nie en, tweedens, gebruik hy die term bestaan (existence) in hierdie konteks in die sin wat dit in die algemene gebruikstaal het - nie in die betekenis wat ek vroeèr bespreek het nie (kyk Pax 1972:73).

"A la limite, qu'est-ce que prouver? C'st faire reconnaître à un autre, qui peut d'illeurs être moi-même, que du moment où il admet une certaine proposition, il est tenu d'dmettre aussi telle autre proposition qui n'st ditincte de celle-là qu'n apparence, et que, livré à lui-même, il mettait en doute." Wat is bewys uiteindelik? Dit is om 'n ander persoon, wat egter ook ekself kan wees, te laat insien dat van die oomblik af wat hy 'n sekere proposisie aanvaar, hy ook verplig is om 'n sekere ander proposisie te aanvaar, wat net oënskynlik anders is as die eerste een en wat hy op sigself geneem, betwyfel het.] Met dié woorde begin Marcel se essay Méditation sur l'idée de preuve de l'existence de Dieu (1940:260) [Bepeinsing oor die idee van 'n bewys van die bestaan van God]. Wanneer bewyslewering fenomenologies ontleed word, blyk dit dat dit altyd 'n bewys aan iemand is. Die kommunikasie beweeg van iemand wat reeds die deduksie uit proposisies gemaak het, na iemand wat dit nog moet doen en is uiteindelik gebaseer op die ontologiese eenheid tussen die eerste proposisies en dit wat daaruit volg (bv die bestaan van God). Daarom kan dit aanspraak maak op universele geldigheid.

Maar uit die geskiedenis weet ons dat nie alle mense wat met die bewyse gekonfronteer is, die pad van bewysvoering saamgeloop het nie. Dit kan moontlik op twee maniere verklaar word: Eerstens kan dit dalk weens denkfoute in die bewys wees, maar aangesien bekwame filosowe onder beide die aanhangers en verwerpers van die bewyse tel, kan die bewyse net so min sonder meer aanvaar as sonder meer verwerp word. Tweedens kan dit dalk toegeskryf word aan 'n moedswillige verset teen die bewys. Hier moet die bewysvoerder empatie met sy of haar gespreksgenoot hê. Dit is dalk omdat God se bestaan as onversoenbaar met die ervaring van lyding in die wêreld beskou word. Of anders is dit 'n onwilligheid om die perke van sy of haar eie bestaan te 
erken. So 'n persoon wil nie dat God bestaan nie, omdat dit 'n afhanklikheid van God sou impliseer, wat indruis teen die drang tot vryheid. Dit is juis die probleem: Die doel van die bewys - die hoogste goed of die wenslikheid van die bestaan van God al dan nie - vir die bewysvoerder en die nie-gelowige is in stryd met mekaar en daarom verloor die middel tot die doel (die bewys) die nodige krag.

Bewys benodig dus 'n gemeenskaplike vertrekpunt. ${ }^{24}$ Die bewys is universeel vir sover dit op die aanvaarding van gemeenskaplike waardes berus. Dié aanvaarding gaan die bewys vooraf en die bewys word dus juis moeilik waar dit die meeste benodig word daar waar mense se tradisie van waardes verskil. Juis hier lê die swak punt van die Godsbewyse: dit ignoreer die verskillende konkrete omstandighede waarin die behoefte vir die bewys ontstaan en die aanvaarding van 'n trans-historiese, konstante, homo naturalis wat daarmee saamgaan.

In teenstelling hiermee meen Marcel dat die mens as homo historicus gesien moet word. Nou word die belang van Marcel se antropologie duidelik. Omdat die mens 'n historiese wese is, kan die mensdom ook agteruit gaan tot waar die vraag "Wie is ek?" nie meer sinvol beantwoord kan word nie, tot waar die mens net nog 'n versameling funksies in die samelewing is ( $\mathrm{kyk}$ bo).

When people can no longer effectively ask the question of self identity in its ultimate reaches or cannot even experience any need or sense in reaching for an ultimate question, they are living in what Marcel calls a broken world, le monde cassé. And since this break in the human world is historically united with an over-confidence in the power of objective knowledge and an excessive respect for all that can be grasped or acquired, it seems highly unlikely to Marcel that the break can be healed by a further dependence upon objective knowledge in the form of a logical demonstration of the existence of a transcendent basis for man's existence.

$(\operatorname{Pax}$ 1972:80)

\footnotetext{
24 "La preuve est un moment dans une certaine éristique intérieure qui demeure malgré tout subordonné à la position d'un invariant, ou, si l'on veut, d'une système de valeurs incontestées en tant que valeurs" (Marcel 1940:266).
} 
Ons moet met ander woorde afsien van Godsbewyse wat berus op eerste refleksie en die "bewys"-situasie allereers verstaan as kommunikasie tussen twee mense. Dit wat die Godsbewyse wil kommunikeer, is die oorgawe aan God, uitgedruk in die vorm: "Ek glo in U, wat my enigste heenkome is" (Je crois en Toi, qui est mon recours unique) (Marcel 1940:271). Die kommunikasie is 'n oorvertel (wat ook getuienis genoem word) of tweede refleksie van die gelowige se geloofservaring soos dit gestalte vind binne die konkrete, historiese lewe (eksistensie). Hierdie eksistensiële gesitueerdheid, die deelname aan die syn, waarin die geloof ingebed is, gaan enige poging tot objektiewe bewysvoering vooraf, en is die basis van die mens se openheid, beskikbaarheid (disponiblilité) tot die syn. Nou behoort dit ook duidelik te wees waarom 'n bespreking van Marcel se nadering tot God nie sonder 'n biografie van hom kan klaarkom nie. Geloof is 'n misterie van Marcel se lewe, wat hy aan ons wil kommunikeer en hiervan getuig hy -

... cette réalité à laquelle je m'ouvre en l'invoquant ne peut plus en aucune façon être assimilée à une donnée objective sur laquelle je m'interrogerais et dont j'aurais à déter-miner rationnellement la nature. Je dirais volontiers que cette réalité me donne à moi-même dans la proportion où je me donne à elle; c'est par la médiation de l'acte par lequel je me centre sur elle que deviens véritablement sujet ... être sujet n'est pas un fait ou un point de départ, mais une conquête et un but. [... hierdie werklikheid waartoe ek my oopmaak deur dit aan te roep, kan nie meer op enige manier beskou word as 'n objektiewe gegewene waaroor ek sou wonder en waarvan ek die aard rasioneel sou moes vasstel nie. Ek sou geredelik kon sê dat hierdie werklikheid vir my aan myself gee in die mate waarin ek my daaraan gee; dit is deur bemiddeling van die daad waardeur ek my daarom sentreer, dat ek waarlik subjek word ... om subjek te wees is nie ' $n$ feit of 'n vertrekpunt nie, maar 'n verowering en 'n doel.]

(Marcel 1940:271)

Kan 'n mens oor hierdie strewe na subjektiwiteit, oor hierdie beweging van die konkrete eksistensie na die aanroeping van God, beter reflekteer? Marcel se antwoord hierop is: Ja. Sy antwoord op hierdie vraag vorm die kern van sy nadenke oor die manier 
waarop die mens tot die misterie van die verhouding met God nader. Met my kursoriese bespreking wil ek daarop wys dat al die aspekte van Marcel se denke hier konvergeer.

\subsection{Drie konkrete naderings tot die synsmisterie}

Ons het reeds gesien dat intersubjektiwiteit ' $n$ besondere venster is op die mens se synsdeelname en tewens ons verstaan van die syn. Van hierdie "konkrete naderings tot die synsmisterie" sê Marcel dat mens hulle kan soek.

... non point dans le registre de la pensée logique dont l'objectivation soulève une question préalable, mais plutôt dans l'élucidation de certaines données proprement spirituelles, telles que la fidélité, l'espérance, l'amour, où l'homme nous apparaît aux prises avec la tentation du reniement, du repliement sur soi, du durcissement intérieur .... ${ }^{.25}[. .$. nie in die lyn van logiese denke waarvan die objektivering ' $n$ voorafgestelde vraag stel nie, maar eerder in die toeligting van sekere ware geestelike gegewenes, soos trou, hoop, liefde, waarin ons die mens sien worstel met die versoeking van verwerping, van onttrekking van jouself, van innerlike verharding ....]

(Marcel 1935:173).

\subsubsection{Trou}

Van hierdie drie naderings, beskou Marcel trou, vanuit 'n ontologiese oogpunt gesien, as die betekenisvolste (Marcel 1935:173).

Marcel verduidelik dit met 'n voorbeeld uit die alledaagse lewe. As ek tydens 'n besoek aan 'n siek mens belowe ${ }^{26}$ om weer te kom kuier, oefen ek beheer uit or my toekomstige vorme van eksistensie. Ek transendeer die blote vloei van een gebeurtenis

25 Ons het vroeerr reeds aan die drie belangrike konkrete naderings - trou, liefde, hoop - geraak (sien aanhaling van Kampits 1975:66-7 [2.1]). Hierdie belangrike aanhaling van Marcel vervolg: "... sans que le pur métaphysicien soit en mesure de décider si le principe de ces tentations réside dans la nature elle-même considérée dans ses caractéristiques intrinséques et invariables, ou bien dans une comption de cette même nature survenue à la suite d'une catastrophe qui aurait donné naissance à l'histoire plutôt qu'elle ne s'y insérerait".

${ }^{26}$ Die idee van die filosofiese waarde van die belofte kry Marcel van Nietzsche - die mens is die enigste wese wat beloftes kan maak (kyk Marcel 1935:16). 
na 'n ander (soos die afsonderlike beelde van 'n rolprent) deur myself aan iemand anders te bind. In die voltrekking van hierdie verbintenis aan ' $\mathrm{j} y$ word die syn geopenbaar. "Je ne me soucie de l'être que pour autant que je prends conscience plus ou moins distinctement de l'unité sous-jacente qui me relie à d'autres êtres dont je pressens la réalité." [Ek het 'n besorgdheid vir die syn net vir sover as wat ek min of meer duidelik bewus word van die onderliggende eenheid wat my verbind aan ander wesens van wie ek 'n voorgevoel het] (aangehaal in Ogiermann 1964:184). ${ }^{27}$ Die syn, wat vir my en jou omarm en konstitueer, is die moontlikheidsvoorwaarde vir die transendering, wat die daad van trou behels. Dit waarin trou veranker is, moet absoluut wees sodat dit as ' $t$ ware borg kan staan vir die trou, wat absoluut moet wees. Maar ons weet dat die oorgawe van hom of haarself, van een mens aan ' $n$ ander, beperk word deur verraad of misleiding. Ook die dood stel perke aan trou - die dood bedreig die teenwoordigheid, en so die beskikbaarheid, van een mens aan ' $n$ ander. Daarom is dit nodig dat trou gewortel moet wees in onwrikbare teenwoordigheid. Vanuit die syn, wat die absolute verankering van trou is, hoor ons die appèl van die ontologiese begeerteleis - dit is die onwrikbare teenwoordigheid van die Absolute Jy, van God. Die vermoè waarmee die mens hom/haarself aan die syn heg, is geloof (Marcel 1927:228); die geloof is gerig op die geheel van die syn en uiteindelik op die Absolute Jy.

\subsubsection{Hoop}

Hoop is, soos trou, gewortel in beskikbaarheid (disponibilité). Marcel kontrasteer hoop met begeerte. Begeerte is 'n houding waarin die beskikking oor spesifieke objekte afgewag word. Dit is 'n berekening van moontlike uitkomste en berus op objektivering.

Hope on the other hand does not try to predict or even imagine what its outcome will be. Genuine hope stems instead from a total openness or availability [disponibilite] on the part of the person who hopes ... it is a steadfast refusal to be bound by the limits which calculation would impose ... Whereas calculation and techniques are confined to the sphere of problematic

\footnotetext{
${ }^{27}$ Nou kan ons beter verstaan wat die betekenis is van die bekende dagboek-inskrywing: "De l'être comme lieu de la fidélité. D'où vient que cette formule qui a jailli en moi, à un instant donné du temps, présente pour moi la fécondité inépuisable de certaines idées musicales? Accès à l'ontologie. La trahison comme mal en soi" (Marcel 1935:55-56).
} 
thought and are concerned with "having" or possession, hope arises only in the realm of mystery and is always concerned with being.

(Hanratty 1976:406)

Die aard van hoop word bo alles vertoon daar waar dit oor wanhoop seëvier. Wanhoop ervaar die mens as beperk deur tyd, soos in die geval van die dood. Hoop oorskry die perke van tyd. Dit is moontlik omdat hoop uiteindelik 'n beskikbaarheid is aan dit wat absoluut teenwoordig is aan alle tye - dit is God, aan wie geen perke gestel kan word nie.

\subsubsection{Liefde}

Ons het reeds gesien dat liefde die gemeenskaplike grond vir samesyn is. Die manier hoe $e k$ en $j y$ ons word deur liefde, is analoog aan die manier hoe $e k$ en $j y$ in beskikbaarheid aan mekaar deur trou gebind word - beide is gegrond in die mens se deelname aan die syn:

Die Liebe dagegen ist die gegenwärtige Teilname am Sein, an der Person Selbst. Sie ist vollendete Partizipation am Leben des geliebten Du. Sie trifft ein Unendliches, denn ihr Du ist niemals ein begrenzter Inhalt ... Der Kreis der Liebe ist der Bezirk des Seins, dessen innere Kontinuităt keinesfalls selbstgenügsame Abgeschlossenheit bedeutet, sondern im Gegenteil Beziehung von Sein zu jedem Sein. Liebe is ein unendliches Gespräch ohne Worte ... Die Liebe individualisiert, indem sie das Ich aus seiner abgeschlossenen Horizontlosigkeit hervorruft und zu sich selbst befreit ... Die Liebe ist Anrufung aus dem Geheimnis. Ihr Gegenstand offenbart sich.

(Berning 1973:220-221)

God, wat die grond van die syn is waaraan ons in liefde deelneem, is die oorsprong van liefde. Liefde is altyd gerig op 'n persoon. Dit streef altyd na al meer omvattende verwerkliking en so mond dit uit in die volle verwerkliking in God. God is die Persoon aan wie ek my ten volle oorgee, vir wie ek nie kan objektiveer nie - dit is wat 
bedoel word as God die Absolute Jy genoem word - "Lorsque nous parlons de Dieu, ce n'est pas de Dieu que nous parlons" [Wanneer ons oor God praat, is dit nie God oor wie ons praat nie] (Marcel 1940:61). Die gepaste manier hoe die oorgawe aan God by uitnemendheid tot uitdrukking kom, die optrede waarin God as Jy deur deelname erken word, is gebed. In gebed praat 'n mens nie oor God nie, maar met God.

\subsection{Oor die verhouding filosofie-openbaring}

Ten slotte wil ek 'n paar gevolgtrekkings maak oor die verhouding filosofie-openbaring. Marcel het nêrens die vraag oor die verhouding tussen filosofie en openbaring spesifiek die tema van sy nadenke gemaak nie. Tog staan sy denke duidelik nie neutraal ten opsigte van die Christelike geloof nie. Dit blyk al uit die ooreenkomste in terme. Ek het ook al genoem dat Marcel filosofeer in "para-Christelike sones" (kyk Deel 1). Dit beteken dat die Christelike openbaringsgeloof ' $n$ historiese veronderstelling van Marcel se denke is. Maar beteken dit dat die Christelike openbaring ook 'n denkveronderstelling van sy denke is? Nee, tewens Marcel handhaaf ' $n$ sterk onderskeid tussen denke en openbaring:

Je tiens d'ailleurs à faire remarquer que du point de vue que est le mien la distinction entre le naturel et le surnaturel doit être rigoureusement maintenue .... il n'est pas question à mes yeux de confondre les mystères enveloppés dans l'expérience humaine en tant que telle - la connaissance, l'amour, par exemple - et les mystères révélés, comme l'Incarnation ou la Rédemption; à ces mystères-là nul effort d'une pensée réfléchissant sur l'expérience ne peut nous permettre de nous élever.' [Ek sou graag wou opmerk dat volgens my eie standpunt die onderskeid tussen die natuurlike en die bo-natuurlike streng behou behoort word .... in my oë is daar geen sprake daarvan om die misteries wat omhul is in menslike ervaring as sodanig - soos byvoorbeeld kennis en liefde - te verwar/vermeng met geopenbaarde misteries soos die inkarnasie of verlossing nie; geen denk-inspanning wat oor ervaring nadink, kan ons in staat stel om laasgenoemde misteries te bereik nie.]

(Marcel [1933]1949:90). 
Maar ons het gesien hoe die mens deur tweede refleksie tot die synsmisterie nader en uiteindelik ook tot God nader, omdat God die grond van die syn is. Daarom kan Marcel sy posisie as volg kommentarieer:

\begin{abstract}
Une ontologie ainsi orientée est évidemment ouverte dans la direction d'une révélation, qu'elle ne saurait d'ailleurs ni exiger, ni présupposer, ni intégrer, ni même absolument parlant comprendre, mais dont elle peut en quelque mesure préparer l'acceptation. Il est possible, à vrai dire, que cette ontologie ne puisse se développer en fait que sur un terrain préalablement préparé par la révélation." ['n Ontologie wat so georiènteer is, is duidelik oop in die rigting van 'n openbaring, wat dit egter nóg sou kon vereis, nóg vooronderstel, nóg integreer, en selfs nie, streng gesproke, sou kon verstaan nie, maar waarvoor dit tot 'n mate die ontvangs kan voorberei. Dit is moontlik, om die waarheid te sê, dat hierdie ontologie in feite sigself net kan ontwikkel op 'n terrein wat vooraf deur die openbaring voorberei is.]
\end{abstract}

(Marcel 1935:174)

Marcel sien die ontologiese misterie as die bestraling van openbaring, wat alle mense, godsdienstig of nie, raak. Sy ontologie veronderstel dus geen geloofsverbintenis nie, maar dit help mense wel om die openbaring te bedink (kyk Marcel [1933] 1949:91).

\title{
5. WAARDERING
}

Ek wil 'n paar punte van kritiek noem waarby 'n vraagteken tot verdere besinning geplaas kan word:

- Hoe hanteer Marcel die konflik in die onderskejd tussen die eenheid van ons en die onderskeid van $e k$ en jy (sien voetnoot 23)? Is die verhouding tussen die ek en die ander noodwendig simmetries - hoe lyk Marcel as ons hom deur die oë van Levinas se eie filosofie lees?

- Word die medemens nie vergoddelik as ek die roep van God bo alles in die aangesprokenheid deur my medemens hoor nie (Janke 1982:154)? 
- Hoe kan die vermoede dat Marcel se konkrete, intersubjektiewe nadering tot God net 'n projeksie is - 'n kritiek vanuit Feuerbach se godsdiensfilosofie (sien Janke 1982:155) - weerlê word? Of sê Marcel enigiets meer as Durkheim, soos Van der Merwe (1996:25) sy posisie opsom: "Godsdiens is 'n neweproduk van die gemeenskapsbestaan .... In sy ontmoeting met die kollektiewe persoon en bewussyn van die gemeenskap kry die indiwidu sy eerste ontmoeting met 'n soort transendentale werklikheid en daaruit groei die konsepsie van transendensie"?

- Wat is, volgens Marcel, die verskil of die verhouding tussen die syn en God?

- $\quad$ Ontsnap Marcel aan die beskuldiging dat hy 'n fideïsme bedryf?

Iemand wat kritiek opper en oordink, moet in berekening hou dat Marcel se onderskeid tussen eerste en tweede refleksie 'n groot klomp besware teen sy denke ontwapen. Dit is maklik om Marcel oënskynlik te weerlê op 'n manier wat eintlik sy perspektief bevestig. Dit vra 'n besondere kompetensie ten opsigte van Marcel se denke om dit te kan evalueer. My voorlopige vermoede is dat Marcel se eiesoortige styl, sy weiering om die werklikheid met 'n geheelsisteem te probeer vasvang, hom in gunstige lig sal stel onder 'n rede-kritiese loep (vgl bv Adorno se "Das Ganze ist das Unwahre" met Marcel se weiering om sisteme te bou). Die metafisiese sy van sy denke sal egter bevraagteken word in ons tyd waarvan sommige mense sê dat dit na die "einde van metafisika" is. Hierdie eskatologiese uitsprake in filosofie kom egter ook onder skoot en daarby is Marcel se metafisika nie so eenduidig nie - dink byvoorbeeld aan die paradoks in die titel van sy boek Journal Métaphysique [Metafisiese dagboek]. Hierbenewens lyk dit of Marcel se denke oor God ge-eggo word in kontemporêre besinnings oor die aanroeping van God - so byvoorbeeld vanuit hermeneutiese rigting, die gewilde werk van Caputo (1987 - met gebruikmaking van Kierkegaard, Heidegger en Derrida) of vanuit fenomenologiese rigting (kyk die bespreking oor "Die teologiese wending in Franse fenomenologie" - Janicaud 1991 - en "Christendom en fenomenologie" - Bernet 1996).

Sekere aspekte van die Hervormde teologiese tradisie bied goeie aansluitingspunte waardeur Marcel teologies oordink kan word: 
- Loader sê dat die Ethischen hulle naam te danke het aan hulle oriëntasie aan 'n bepaalde waarheidsbeskouing: om te sê "die waarheid is eties", beteken "[d]ie wese van waarheid is dat dit in ' $n$ lewende ontmoeting met God tot die mens kom en nie in proposisies nie." (Loader 1996:578). Dit is wat Marcel bedoel as hy sê: “... as ek oor God praat is dit nie meer oor God wat ek praat nie." (kyk 3.2.3)

- As Brunner vanuit die dialektiese teologie die Protestantse waarheidskonsepsie opsom as Wahrheit als Begegnung, dan som hy ook Marcel se siening op die nadering van die synsmisterie op.

- Benewens hierdie twee punte, waar die etiese- en dialektiese teologie 'n sterk affiniteit vir mekaar toon (volgens Loader 1996:583-5), kan die gepaardgaande beskouing oor die beperktheid van teologie-uitsprake en die transendering van die subjek-objek skeiding as aansluitingspunt genoem word.

Vir ons homines viatores wat in ons konkrete lewensomstandighede gelowig en denkend op pad is, is Marcel beskikbaar as katalisator in samesyn met mense en God.

\section{Literatuurverwysings}

Bernet, R 1996. Christendom en Fenomenologie. Tijdschrift voor Filosofie 58(4), 755 749.

Berning, V 1973. Das Wagnis der Treue: Gabriel Marcels Weg zu einer konkreten Philosophie des Schöpferischen. München: Karl Alber.

Bollnow, O F 1965. Französischer Existentialismus. Stuttgart: W Kohlhammer.

Caputo, J D 1987. Radical hermeneutics: Repetition, deconstruction, and the hermeneutic project. Indianapolis: Indiana University Press.

Delfgaauw, B 1969. Wat is existentialisme? Baarn: Het Wereldvenster.

Hanratty, G 1976. The religious philosophy of Gabriel Marcel. HeyJ 17, 395-412.

Janicaud, D 1991. Le tournant théologique de la phénoménologie française. Combas: L'éclat.

Janke, W 1982. Existenzphilosophie. Berlin: de Gruyter.

Kampits, P 1975. Gabriel Marcels Philosophie der zweiten Person. Wien: R Oldenbourg. 
Levinas, E [1978] 1987. Martin Buber, Gabriel Marcel et la philosophie, in Hors sujet. Paris: Fata morgana.

Marcel, G 1925. Existence et objectivité, in Marcel 1927.

- 1927. Journal Métaphysique. Paris: Gallimard.

— [1933]1949. Position et approches concrètes du mystère ontologique. Paris:Vrin.

- 1935. Être et avoir. Paris: Aubier.

- 1940. Essai de philosophie concrète. Paris: Gallimard.

Ogiermann, H 1954. Gottes Existenz im Denken Gabriel Marcels. Scholastik 29, 174209.

Pax, C 1972. An existential approach to God: A study of Gabriel Marcel. The Hague: Marthinus Nijhoff.

Ricoeur, P [1984] 1992. Réflexion primaire et réflexion seconde chez Gabriel Marcel, in Lecteurs 2. La contreé des philosophes. Paris: Seuil.

Van der Merwe, P J 1996. Teologiese godsdiensfilosofie. Ongepubliseerde kernaantekeninge GSW610, Fakulteit Teologie, Universiteit van Pretoria.

Wolff, E 2000. Gabriel Marcel se lewe en werk as agtergrond van sy benadering tot God, deel I. HTS 56(2\&3), 836-848. 